\title{
FREEDOM OF SPEECH IN FOOTBALL STADIUMS. ARE FOOTBALL SUPPORTERS ALLOWED TO DO MORE OR LESS THAN AN ORDINARY CITIZEN?
}

DOI: http://dx.doi.org/10.12775/TSP-W.2020.019

Date of receipt: 28.04 .2020

Date of acceptance: 21.10 .2020

\begin{abstract}
Summary. Football fans support their teams and prepare tifo. They present their points of view in football stadiums. They refer to the history, politics, their opponents and current activities of the club. Unfortunately, often they insult and swear a lot. Sometimes fans preach fascist or racist ideas. Are football fans often allowed to do more or less than an ordinary citizen? How does their behaviour relate to restrictions on freedom of speech? Why do they sometimes avoid punishment? Where is the borderline between freedom of speech and unauthorized tifo? The authors analyse issues related to the behaviour of football fans in the context of freedom of speech and try to answer these questions.
\end{abstract}

Keywords: sport, football fans, freedom of speech, football stadium.

Wolność słowa na stadionach piłkarskich. Czy kibicom piłkarskim wolno więcej niż zwykłym obywatelom? Kibice piłkarscy wspierają swoje ulubione drużyny i przygotowują specjalne oprawy meczowe. Mają oni możliwość prezentowania własnego punktu widzenia na stadionach piłkarskich. Podczas dopingu odnoszą się między innymi do historii, polityki, swoich przeciwników oraz obecnej sytuacji danego klubu. Bardzo często używają do tego niecenzuralnych słów. Czasami zdarza się, że kibice pro-

${ }^{1}$ Wojciech Kiełbasiński, Mateusz Brzeziński - Faculty of Law and Administration, Nicolaus Copernicus University in Toruń. 
pagują faszyzm lub rasizm. Czy mogą oni pozwolić sobie na więcej niż inni obywatele? Jak ich zachowanie odnosi się do ograniczenia wolności słowa? Dlaczego czasami unikają kary? Gdzie przebiega granica pomiędzy wolnością słowa a wygłaszaniem swoich poglądów i używaniem niecenzuralnych słów w ramach oprawy meczowej? Autorzy analizują kwestię zachowania kibiców piłkarskich na stadionach w kontekście wolności słowa i starają się wskazać odpowiedzi na wymienione pytania.

Słowa kluczowe: sport, kibice piłkarscy, wolność słowa, stadion piłkarski.

\section{INTRODUCTION}

Freedom of speech and expression is one of the most important human rights. It is pointed out that freedom of expression is one of the cornerstones of a democratic society and a condition for the development and self-fulfilment of citizens $^{2}$. People shall have rights to express their views. It should be noticed that this right is not absolute. It cannot violate other rights. An interesting issue is the respect for the right to freedom of speech in football stadiums. Football supporters often prepare special tifo. They refer to the history, politics, their opponents and current activities of the club. Sometimes football clubs receive financial penalties for unauthorised tifo. Per contra football fans oftena void punishment for using abusive language. The borderline between freedom of speech and supporter's behaviour is very thin. Case studies from European stadiums show that individual countries have very different approaches to this issue. Currently "the law is increasingly and frequently penalising minor, albeit uncivilised, behaviour such as aggressive and abusive language, which has served as an integral element of traditional football culture"3.

\section{FREEDOM OF SPEECH IN POLISH LAW}

Under Article 54 of the Constitution of the Republic of Poland - the freedom to express opinions, to acquire and to disseminate information shall be ensured to everyone. Protection in this article covers all statements, i.e. all behaviour expressing particular views. These are both verbalized forms and other forms like

2 J. Sadomski, Art. 54 Konstytucji RP, [in:] Konstytucja RP. Tom I. Komentarz do art. 1-86, (ed.) M. Safjan, L. Bosek, Warszawa 2016, Legalis.

${ }^{3}$ D. Antonowicz, R. Kossakowski, H. Jakubowska, A Bittersweet Welcome: Attitudes of Polish Ultra-Fans toward Female Fans Entering Football Stadiums, [in:] Sport in Society 2020, p. 2. 
image, sound, gesture, mimicry, way of dressing or hairstyle ${ }^{4}$. The statement may state certain facts, as well as evaluate them ${ }^{5}$.

Freedom of speech is not absolute ${ }^{6}$. In Polish law it is connected with a general restrictive clause ${ }^{7}$. According to article 31 of the Constitution of the Republic of Poland - any limitation upon the exercise of constitutional freedoms and rights may be imposed only by statute, and only when necessary in a democratic state for the protection of its security or public order, or to protect the natural environment, health or public morals, or the freedoms and rights of other persons. Such limitations shall not violate the essence of freedoms and rights. The restriction must also comply with the principle of proportionality ${ }^{8}$. It is very important to resolve the conflict between freedom of expression and the right to protect a good name ${ }^{9}$. This is related to criminal law and defamation. An offence is also insulting a public officer. It often happens at football matches. It should be emphasized that the freedom of public debate cannot justify using of offensive, aggressive and degrading phrases that violate human dignity ${ }^{10}$.

\section{FREEDOM OF SPEECH IN INTERNATIONAL AND EUROPEAN UNION LAW}

The standard of protection of the right to freedom of speech and expression in international law arises primarily from the protection standards set by the Council of Europe and the European Union as well as from the UN global protection system ${ }^{11}$. The protection of freedom of expression is reflected in Article 19 of the Universal Declaration of Human Rights, according to which everyone has the right to freedom of opinion and expression; this right includes freedom to hold opinions without interference and to seek, receive and impart information and ideas through any media and regardless of frontiers. As the doctrine points out, Article 18 (which constitutes the right to freedom of thought, conscience and religion) together with Article 19 is a great achievement of civilization as it

${ }^{4}$ J. Sadomski, op.cit.

${ }_{5}$ M. Florczak-Wątor, Art. 54 Konstytucji RP, [in:] Konstytucja Rzeczypospolitej Polskiej. Komentarz, (ed.) P. Tuleja, 2019, Lex.

${ }^{6}$ Ibidem.

7 B. Gronowska, Wolności, prawa i obowiązki człowieka i obywatela, [in:] Prawo Konstytucyjne, (Ed.) Z. Witkowski, Toruń 2009, p. 175.

${ }^{8}$ J. Sadomski, op.cit.

${ }^{9}$ Ibidem.

${ }^{10}$ Ibidem.

11 W. Mojski., Konstytucyjna ochrona wolności wypowiedzi w Polsce, Lublin 2014, p. 48. 
guarantees freedom of thought, religion, conscience and freedom to express own opinion as well as freedom of expression ${ }^{12}$.

These rights are confirmed by Articles 9 and 10 of the European Charter of Human Rights. According to paragraph 1 of Article 10, everyone has the right to freedom of expression. This right includes freedom to hold opinions and to receive and impart information and ideas without interference by public authorities and regardless of frontiers. Article 10(2), on the other hand, refers to circumstances in which freedom of expression may be restricted. In the context of considerations of disciplinary responsibility for the behaviour of supporters in football stadiums, the possibility of violating the protection of the reputation and rights of other individuals by crossing the border of freedom of expression is important. On the other hand, it is important to underline that no social and political restrictions that may undermine the rights to freedom of thought and expression are acceptable ${ }^{13}$.

These guarantees are intended to protect citizens from restrictions primarily imposed by state authorities. As it is underlined in the literature, to prevent states from exaggerating in the sphere of civil liberties, they have negative obligations towards their citizens. Interference in the sphere of freedom of expression can only be allowed if it is proportionate and necessary in a democratic society ${ }^{14}$.

The European Court of Human Rights confirms the importance of the right to free expression and its importance for the functioning of democracy. As Kulk and Zuiderveen Borgesius point out "subject to paragraph 2 of Article 10, it is applicable not only to information or ideas that are favourably received or regarded as inoffensive or as a matter of indifference, but also to those that offend, shock or disturb". Subject to Article 10(2), freedom of expression is applicable not only to information or ideas that are favourably received or regarded as inoffensive or as a matter of indifference, but also to those that offend, shock or disturb $^{15}$. Exceptions to the principle of freedom of expression must be interpreted strictly. and the necessity of any restriction must be justified ${ }^{16}$.

12 J. Barański., Wolność myśli jako warunek wolności wyrażania opinii. Filozoficzne rozważania nad opiniq publicznq i poprawnościq polityczna, [in:] Prawa człowieka i ludzkie bezpieczeństwo. Osiagnięcia i wyzwania. W 70. rocznicę ogłoszenia Powszechnej Deklaracji Praw Człowieka, (ed.) D. Bieńkowska, R. Kozłowski, Warszawa 2019, p. 59-61.

${ }^{13}$ Ibidem.

${ }^{14}$ S. Kulk., F. Zuiderveen Borgesius, Privacy, freedom of expression, and the right to be forgotten in Europe, [in:] The Cambridge Handbook of Consumer Privacy, (ed.) J. Polonetsky, O. Tene, E. Selinger, Cambridge 2018, p. 301-320.

${ }^{15}$ Ibidem.

${ }^{16}$ Ibidem. 


\section{TYPOLOGY OF THE FOOTBALL SUPPORTERS}

We can group football fans because of their involvement in supporting club and out of the stadium activity. According to the typology of Mr Albert Jawłowski from the University of Warsaw we can divide football fans into 8 groups ${ }^{17}$.

Table 1. Typology of the football supporters

\begin{tabular}{|l|l|}
\hline \multicolumn{1}{|c|}{ Name of the group } & \multicolumn{1}{c|}{ Description } \\
\hline Official hooligans (chuligani) & $\begin{array}{l}\text { This is the most dangerous group. The matches } \\
\text { are an opportunity for them to fight against } \\
\text { supporters of opposite teams and the police. }\end{array}$ \\
\hline Ultras (ultrasi) & $\begin{array}{l}\text { They prepare tifo. They use flags and } \\
\text { transparents. }\end{array}$ \\
\hline "Animals" (animalsi) & $\begin{array}{l}\text { A group of the most aggressive supporters. } \\
\text { Match is an opportunity for them to take part } \\
\text { in a fight. }\end{array}$ \\
\hline "Holy stink makers" (zadymiarze) & $\begin{array}{l}\text { They are very similar to Animals. He goes to } \\
\text { away matches more often. }\end{array}$ \\
\hline "Scarf-wearings" (szalikowcy) & $\begin{array}{l}\text { They are fans and sports lovers. They are really } \\
\text { interested in sport. They are tied to club colour. }\end{array}$ \\
\hline Fans (kibice) & $\begin{array}{l}\text { They are present at almost every home gameto } \\
\text { support their teams. }\end{array}$ \\
\hline Fanatics (fanatycy) & $\begin{array}{l}\text { The biggest funs of clubs. They can go around } \\
\text { the world with their teams. }\end{array}$ \\
\hline "Picnicers" (piknikowcy) & $\begin{array}{l}\text { They often come to the stadium with children } \\
\text { to watch the matches. }\end{array}$ \\
\hline
\end{tabular}

Source: Own compilation based on the typology of Mr Albert Jawłowski from the University of Warsaw described in paper - T. Łatak, Polscy kibice-chuligani, Katowice 2011.

As we can see, people come to football matches mainly for three reasons: to support their teams, to prepare tifo or to fight against supporters of opposite teams or the police. We can also group football supporters into football hooligans and football fans ${ }^{18}$. Unfortunately, very often everyone bears collective responsibility for the behaviour of individuals. Nowadays football is the sport with the most aggressive fans' behaviour ${ }^{19}$. Sometimes it is connected with organized

\footnotetext{
17 T. Latak, Polscy kibice-chuligani, Katowice 2011, p. 8.

18 Ibidem, p. 21.

19 Ibidem, p. 15.
} 
crime in football hooligan groups ${ }^{20}$. As an example, we can mention groups of hooligans from Chorzow (Psychofans) and Cracow (Sharks) ${ }^{21}$.Stadium hooliganism is evolving and also moves activity outside the stadium, but they care about club colour ${ }^{22}$. Two main areas of their activity are crimes connected with football matches and crimes connected with organized crimes like drug dealing ${ }^{23}$.

\section{THE LEGAL BASIS FOR DISCIPLINARY PENALTIES PROVIDED BY THE POLISH FOOTBALL ASSOCIATION AND THE UNION OF EUROPEAN FOOTBALL ASSOCIATIONS}

The application of the provisions on disciplinary responsibility in sport is an expression of sport's autonomy ${ }^{24}$ and according to Article 13(1)(2) of the Act on Sport, the Polish Sports Association has the exclusive right to establish and implement sports, organizational and disciplinary rules in sports competitions organized by the Association, with the exception of disciplinary rules on doping in sport. In turn, pursuant to Article 45b(1) of this Act, the disciplinary responsibility under the Polish Sports Association is executed under the rules set out in the disciplinary regulations. As it is underlined in the literature of the subject ${ }^{25}$ the disciplinary responsibility in sport is executed by Polish Sports Associations within the scope defined in the disciplinary regulations adopted by the assembly of its members or delegates.

In case of disciplinary violations taking place during the games supervised by the Polish Football Association, it shall be a sports association entitled to apply disciplinary penalties, which is based on its status, according to which, on the basis of art. $6 \S 4$, the Polish Football Association enforces its organizational, disciplinary and statutory responsibility towards all its members (listed in art. $6 \S 2$ of the statute). UEFA, in turn, is an international organisation which unites national football federations and whose task is to supervise and organise international football competitions. As the literature points out, the statutes of

${ }^{20}$ P.Chlebowicz, Tendecje rozwojowe przestępczości zorganizowanej w środowiskach pseudokibiców piłkarskich, [in:] Sport a przestępczość zorganizowana, (ed.) M. Leciak, Warszawa 2018, p. 99.

${ }^{21}$ S. Jadczak, Wisła w ogniu, Kraków 2019.

${ }^{22}$ P. Chlebowicz, op.cit., p. 102.

${ }^{23}$ Ibidem, p. 105.

${ }^{24}$ H. Radke, Odpowiedzialność dyscyplinarna $w$ sporcie, [in:] Prawo sportowe, (ed.) M. Leciak, Warszawa 2018, p. 301-302.

${ }^{25}$ E. Krześniak, Kluby i organizacje sportowe w prawie polskim na tle rozwiazań zagranicznych, Warszawa 2016, p. 515-516. 
international sports federations and other regulations adopted by them do not have the character of general law $^{26}$. Therefore, the adoption of the rules of international sports organisations and their application by national sports federations has a contractual character, applicable under private law ${ }^{27}$. Such an obligation of the Polish Football Association to apply the provisions of UEFA is visible in the statute of the Polish Football Association ${ }^{28}$ in Article 4(2)(a) and (c) and Article 5(2 $)^{29}$. In accordance with Article 59 of UEFA's statutes, UEFA requires its sports organisations to submit to the legal acts published by UEFA ${ }^{30}$.

Before discussing the case studies taking place in football stadiums in Poland and Europe, it is worth to mention the provisions of the disciplinary regulations of the Polish Football Association and UEFA, which are intended to prevent fans from abusing their right to freedom of speech during football matches. The possibility of imposing sanctions on supporters and even more on football clubs means that we do not regularly observe provocative tifo.

\section{POLISH FOOTBALL ASSOCIATION}

The catalogue of penalties that can be imposed on football clubs in connection with infringements during matches is set out in the Disciplinary Regulations of the Polish Football Association ${ }^{31}$. In accordance with Article $2 \S 4$ of the Discipline Regulations, the clubs are liable for the disciplinary offenses of their players, coaches, instructors, medical staff members, football activists and supporters. This means that football clubs are responsible for the behaviour of supporters if they violate the regulations. Supporters will be held personally liable if they violate other legal regulations. An additional penalty that can be imposed on a supporter but does not directly affect the football club is the possibility of a stadium ban in accordance with Article 148. In principle, there are two types of supporter behaviour which will result in disciplinary penalties being imposed

${ }^{26}$ D. Wolski, Regulacje przyjmowane przez międzynarodowe organizacje sportowe a prawo krajowe, [in:] Problemy Wspótczesnego Prawa Międzynarodowego, Europejskiego i Porównawczego, Vol. XIV, Kraków 2016, p. 137.

27 Ibidem

${ }^{28}$ Statute of the Polish Football Association incorporating the modifications from 30 October 2018 .

${ }^{29}$ Ibidem.

${ }^{30}$ UEFA Statutes Rules of Procedure of the UEFA Congress Regulations governing the Implementation of the UEFA Statutes April 2017 edition.

${ }^{31}$ Disciplinary Regulations of the Polish Football Association from 6 December 2019 (consolidated version). 
on the sports club. The first one is related to the violation of Article 67 of the Discipline Regulations by various forms of disdainful or discriminating behaviour by the fans, and the second one will consist in their violation of the facility regulations or mass event regulations. For the purposes of the article, once this distinction has been made, the first type of cases will be considered, as those situations such as those referred to in Article 67 may lead to a conflict with respect of the right to freedom of expression. In accordance with Article 67, for making statements of a disrespectful, grossly unethical nature, praising terrorism, criminality, violence, invoking criminal ideologies, political content, discriminatory content, in particular with regard to race, colour, language, religion or origin, for shouting or committing any other act of such nature during, immediately before or after the match, penalties may be imposed jointly and severally:

a) a football club which is threatened with the following penalties:

1) a financial penalty not lower than PLN 5.000,

2) to verify the competition as a walkover,

3) play the match without an audience;

b) prohibition to play a certain period of time or a certain number of matches with the participation of the public on some or all of the sports facility, in the town where the club is based;

1) a ban on the travel of organised groups of supporters to football matches,

2) exclusion from the games,

3) to relegate the team to a lower division;

c) supporters committing an infringement which threatens to result in a stadium ban of up to 2 years;

d) other natural persons who may receive penalties:

1) disqualification for at least 5 matches or at least 3 months,

2) a fine of not less than PLN 5.000.

The construction of the penalty catalogue clearly focuses on the threat of penalties to the football club in case of violation of the regulations. Such a solution is primarily aimed at preventing supporters from exposing their own club to severe sanctions from the disciplinary authority. A common way of violating the regulations through disrespectful or discriminatory behaviour is through tifo, which are prepared by supporters. It takes the form of e.g. banners, flags, banners hung during the matches. This is why there are special regulations in paragraphs 4 and 5 of Article 67 to punish this type of behaviour. It is also worth noting the construction of these two regulations, because it does not provide for punishment of individuals responsible for hanging an offensive banner, but transfers responsibility to the club. Another provision which does not provide for supporters' li- 
ability is Article 77 concerning degrading statements. In the event of a breach of this provision, the penalties may be imposed on individuals, i.e. those who may be penalised in accordance with the catalogue of basic penalties set out in Article 13(2) of the Discipline Regulations. It is worth to mention that Disciplinary Regulations does not define the term physical person. Such a way of excluding supporters from the catalogue of entities threatened with a disciplinary sanction under Article 77 seems to be an unclear solution, but it is obvious that it would be impossible to control or even less penalise supporters for undiplomatic comments made during a football match.

\section{THE UNION OF EUROPEAN FOOTBALL ASSOCIATIONS}

The legal basis for imposing penalties by UEFA are similar to those contained in the disciplinary regulations of the Polish Football Association. These provisions are contained in UEFA Disciplinary Regulation $\mathrm{s}^{32}$. Article 3 defines the catalogue of entities subject to the disciplinary rules. This catalogue does not mention supporters, however, as follows from the following regulations, a football club may be held responsible for their violation of the rules of discipline. This form of responsibility is laid down in Article 8 of the rules, according to which a member association or a club which is bound by a rule of conduct laid down in the statutes or rules of UEFA may be subject to disciplinary measures and directives if such a rule is breached as a result of the conduct of one of its members, players, officials or supporters or any other person acting on behalf of the member association or club concerned, even if the member association or club concerned can prove the absence of any fault or negligence. As is the case with the regulations of the Polish Football Association, the possible penalty will mainly be aimed at the football club whose supporters are infringing the regulations.

UEFA acts very strongly against all forms of racism in stadiums, as expressed in Article 14 of the disciplinary regulations. According to its second paragraph, if one or more member associations or supporters of the club engage in racist behaviour (as defined in paragraph 1), the member association or the responsible club is punished with a minimum partial closure of the stadium. The following paragraphs of this article provide increased penalties depending on the degree of infringement and recidivism. The provision that will most often be used to impose disciplinary penalties for supporter behaviour in stadiums is Article 16(1). Article 16(2) of the rules, according to which all associations and

\footnotetext{
${ }^{32}$ UEFA Disciplinary Regulations Edition 2019.
} 
clubs are responsible for the following misbehaviour of their supporters and may be subject to disciplinary measures and guidelines, even if they can prove that they have not committed any negligence in connection with the organisation of the match. This provision contains eight types of violations that can be committed by supporters:

a) the invasion of the field of play;

b) the throwing of objects potentially endangering the physical integrity of others present at the match or impacting the orderly running of the match;

c) the lighting of fireworks or any other objects;

d) the use of laser pointers or similar electronic devices;

e) the use of gestures, words, objects or any other means to transmit a provocative message that is not fit for a sports event, particularly provocative messages that are of a political, ideological, religious or offensive nature;

f) acts of damage;

g) causing a disturbance during national anthems;

h) any other lack of order or discipline observed inside or around the stadium

Interesting provision from the point of view of the subject matter of the paper is point (e). Annex A to the Rules of Procedure provides for a penalty of EUR 10000 for the first infringement and EUR 15000 for the second infringement in case of offence, which does "not fit for a sports event". However, fines may be increased per each additional case of repetition.

As can be seen, UEFA's disciplinary rules contain more general provisions which may subject fans' misbehaviour during a football match. It is worth pointing out that these rules do not address the personal responsibility of supporters or the imposition of penalties for stadium bans, which is a matter of applying national regulations.

\section{CASES FROM POLISH FOOTBALL STADIUMS}

Polish fans are one of the most recognizable in the world. The excellent atmosphere in Polish stadiums is very often highlighted. However, Polish supporters are also known for their bad side. Polish clubs very often get penalties for their fans' behavior.

Polish fans often insult the police, politicians, opponents or club owners. It is pointed out that the police are the football hooligans' greatest enemy ${ }^{33}$. Hatred

33 T. Łatak, op.cit. 
is shown during the matches. Most often hooligans don't get any punishment for it. However, under the criminal law they should be punished. Usually only clubs get the penalty for their fans' behaviour. In 2020 during the game, between Legia Warsaw and ŁKS Łódź, Legia Warsaw's supporters hung a banner with writing: "Mr. Nitot. It's not too late to back out. You've still got customers, the company's still in business." It was related to the interest in the acquisition of the Polonia Warsaw by Mr. Nitot. They also hung a banner to intimidate a young fan. Based on the decision of the disciplinary body of 12.02.2020 club, the club received a 50000 PLN fine. The Chairman of disciplinary body said that "Fans, hanging the mentioned banners and threats towards a potential investor of Polonia Warsaw and a young player of Legia, have exceeded the allowed limits of doping" ${ }^{34}$. In 2015 several clubs got punished in connection with to supporter's behavior. They expressed their dissatisfaction with the plans to admit refugees to Poland. Clubs got financial penalty. Clubs had to organise meetings with fans to present the policy of the Ekstraklasa SA against discrimination ${ }^{35}$.

Legia Warsaw also received many different penalties from UEFA Control, Ethics and Disciplinary Body. In august 2017 Legia's fans prepared tifo referred to the history. There was a banner - "During the Warsaw Uprising Germans killed 160000 people. Thousands of them were children". Above it was a picture of a German soldier with a gun to the head of a child. Legia got 35000 Eur fine because of illicit banner and stairways blocked ${ }^{36}$. Fans disagreed with this decision. They organized a fundraiser to pay the penalty. The fans collected over PLN $387000^{37}$. For the next match the fans have prepared another tifo. They showed UEFA as pigs, additionally holding up blow-up plastic pigs. There was also a banner - "And the $35000 €$ fine goes to..." Club got 50000 Eur fine because of setting off of fireworks and illicit banner ${ }^{38}$.

${ }^{34}$ Ekstraklasa, Decyzje Komisji Ligi z dnia 12.02.2020, https://ekstraklasa.org/aktualnosci/ decyzje-komisji-ligi-z-dnia-12-02-2020-14444 [access: 28.03.2020].

${ }_{35}$ P. Majewski, Komisja Ligi ukarała kluby za okrzyki na temat uchodźców, https://wmeritum.pl/komisja-ligi-ukarala-kluby-za-okrzyki-na-temat-uchodzcow/120073 [access: 28.03.2020].

${ }^{36}$ Kara dla Legii jednak za oprawę. Jest petna decyzja UEFA, https://www.wprost.pl/pilka-nozna/10070848/Kara-dla-Legii-jednak-za-oprawe-Jest-pelna-decyzjaUEFA.html (available 6 April 2020).

${ }^{37}$ pomagam.pl, Opłacenie kar za oprawe na Legii, https://pomagam.pl/Powstanie1944 [access: 28.03.2020].

${ }^{38}$ UEFA, Case Law Control, Ethics and Disciplinary Body Appeals Body CFCB Adjudicatory Chamber, https://editorial.uefa.com/resources/0258-0e30442ef9a5-52f6cb6280b1-1000/ uefa_competitions_cases_july_-_december_2017.pdf?fbclid=IwAR3LYn9zupdmeQBKHmyq8g mYv752DOB93Az5uyczk00TyHFzn2qYoXI5SXs [access: 28.03.2020]. 


\section{CASES FROM INTERNATIONAL FOOTBALL STADIUMS}

One of the legal acts connected with aggressive and abusive language in football stadiums was enacted in Scotland in 2012. It was proposed after match between Celtic and Rangers in March 2011 - in this time there was a lot of incident connected with violence and aggressive language ${ }^{39}$. The act titled the Offensive Behaviour at Football and Threatening Communications Act caused protest amongst supporters. They felt that their right to express their opinions had been infringed ${ }^{40}$. This act has been criticized by many people, including Human Rights organisations ${ }^{41}$. The act was described as having a chilling effect on free speech and freedom of expression ${ }^{42}$. According to this legislation a person commits an offence if, in relation to a regulated football match engages in behaviour of a kind described in this act and the behavior is likely to incite public disorder would be likely to incite public disorder. The behaviour is e.g. expressing hatred of or stirring up hatred against, a group of persons based on their membership or presumed membership of a religious group. A person guilty of an offence is liable on conviction on indictment, to imprisonment for a term not exceeding 5 years or to a fine or to both - or on summary conviction, to imprisonment for a term not exceeding 12 months, or to a fine not exceeding the statutory maximum, or to both. In 2015 An evaluation of Section 1 of the Offensive Behaviour at Football and Threatening Communications (Scotland) Act 2012 was published $^{43}$. The Act was repealed on 20 April 2018.

In Ukraine, restrictions on football supporters were introduced also. The conflict began because of match between Dynamo Kyiv and Karpaty Lviv in 2011 when Dynamo supporters attacked a stadium worker who tried to remove a flag of Karpaty fans related to historic leader to the Ukrainian national-patriotic movement ${ }^{44}$. The result of this incident was a number of oppressive measures

${ }^{39}$ M. McBride, The Offensive Behaviour at Football and Threatening Communications (Scotland) Act 2012 - Assessing the Case for Repeal, [in:] Edinburgh Law Review 21, nr 2 (May 2017), p. 234.

${ }^{40}$ D. Antonowicz, R. Kossakowski, H. Jakubowska, op.cit., p.2.

${ }^{41}$ M. McBride, op.cit.

42 Ibidem.

${ }^{43}$ Scottish Government, An evaluation of Section 1 of the Offensive Behaviour at Football and Threatening Communications (Scotland) Act 2012, https://www.gov.scot/publications/ evaluation-section-1-offensive-behaviour-football-threatening-communications-scotland-act-2012 [access: 28.03.2020].

${ }^{44}$ A. Shvets, Legal Responses to 'Football Hooliganism' in Ukraine, [in:] A. Tsoukala, G. Pearson, P. T.M. Coenen [Ed.], Legal Responses to Football "Hooliganism" in Europe, 2016, p. 151. 
taken against football supporters in Ukraine, including stricter searches while entering the stadia, confiscation of certain symbols, a prohibition on certain traditional chants and questioning of fans by the militia ${ }^{45}$. The authorities wanted to introduce a new act included administrative liability of football fans for demonstration of banners of a political nature ${ }^{46}$.

One of the recent examples of abuse of freedom of speech took place during the match between Hoffenheim and Bayern Munich on 29 February 2020. Due to the supporters who hung a banner insulting the host president Dietmar Hopp, the match was interrupted. Later the match was resumed, but the players pretended to play as a protest. This situation is the result of a conflict between German supporters and President of Hoffenheim Dietmar Hopp, who is one of the richest people in Germany. He has invested a lot of money into a club that had no great traditions or successes in its history. Within a few years he managed to build a team that has been playing in the Bundesliga continuously for 12 years. In the fan community there is a large group of people who are opposed to this type of practice and believe that investing huge amounts of money in football destroys the traditions of this sport. They are united around the slogan "against modern football". In contrast to the " $50 \%+1$ " rule in German football, Dietmar Hopp owns $96 \%$ of the club's shares. The $50+1$ rule guarantees that external investors will not simply be able to purchase the entire club. This has led to a lot of criticism from fans throughout Germany, especially from Borussia Dortmund supporters. Dietmar Hopp decided that such behaviour shall be punished. As a result of the proceedings, which he initiated, some Borussia Dortmund's fans, who insulted him during the match, were punished. Two fans accepted fines of $€ 400$ and $€ 600$, while the other three argued their defence with the help of lawyers, claiming that their criticism of Hoffenheim's management model is justified and that the insults were not aimed at defaming Hopp personally, also highlighting the sharper, more severe language prevailing among football fans ${ }^{47}$. This only exacerbated the conflict, which led to Dietmar Hopp's continuing efforts to punish the defamatory supporters. In November 2018, the German Football Association punished Borussia Dortmund with a three-year ban on away matches against the Hoffenheim club and also fined the club 60,000 EUR, suspending the execution for 24 months. The sanctions were also imposed on 32 supporters who

45 Ibidem.

46 Ibidem.

${ }^{47}$ M. Ford, When chants become crimes: Borussia Dortmund fans fined for defamatory songs, https://www.dw.com/en/when-chants-become-crimes-borussia-dortmund-fans-fined-fordefamatory-songs/a-49010074 [access: 28.03.2020]. 
were given stadium bans ${ }^{48}$. It is clear that actions to identify the perpetrators of infringements during football matches can lead to penalties being imposed on individual supporters. There is no doubt that the infringement of other people's rights is a form of abuse of the right to freedom of speech. However, it should be considered whether the imposition of penalties on selected persons is not an example of the use of collective responsibility and the way of identification (through cameras and eavesdropping) is a violation of the right to privacy.

\section{CONCLUSIONS}

Freedom of speech in football stadiums is a very important issue. It should be pointed out that European Court of Human Rights" have started to recognize the rights of groups gathering together for cultural and arguably completely social reasons, thus encompassing dominant forms of European football fandom within the umbrella protection of the ECHR" ${ }^{49}$. It is crucial for the fans who want to defend their freedom of speech.

Case studies from various countries show that there are situations where freedom of speech is not respected. Fans are sometimes forbidden to carry flags, banners or sing songs. That might be human rights violations. However, it should be noted that the borderline between exceeding freedom of speech and supporter's behaviour is very thin. Crossing the borders of freedom of speech by fans causes the financial responsibility mainly charges football clubs. Unfortunately, football clubs are not in a position to effectively influence supporters' behaviour so that they refrain from expressing their opinions in an explicit way during football matches. Football clubs don't want to enter into conflict with their supporters. Nowadays fans rarely receive penalties for using abusive language. We need to create a social campaign and teach supporters to behave accordingly without swearing or insulting. A good instance was shown in the USA. In 2004 in the USA Maryland State University started a campaign connected with fan's behavior and using abusive language by them ${ }^{50}$.

48 Onet, Niemcy: Bayern rozbit TSG Hoffenheim. Skandal na trybunach i protest piłkarzy, https://bundesliga.onet.pl/tsg-hoffenheim-bayern-monachium-skandal-podczas-meczu/3n7lf3w [access: 28.03.2020].

${ }^{49}$ P. T. M. Coenen, G. Pearson, A. Tsoukala, Legal Responses to Football 'Hooliganism' in Europe - Introduction, [in:] A. Tsoukala, G. Pearson, P. T.M. Coenen [ed.], Legal Responses to Football "Hooliganism" in Europe, 2016, p. 11.

${ }^{50}$ E. Bordman, Freedom of speech and expression in sports, [in:] Arts, communications, entertainment and sports law, 2007, p. 37. 


\section{BIBLIOGRAPHY:}

Antonowicz D., Kossakowski R., Jakubowska H., A Bittersweet Welcome: Attitudes of Polish Ultra-Fans toward Female Fans Entering Football Stadiums, [in:] Sport in Society 2020.

Barański J., Wolność myśli jako warunek wolności wyrażania opinii. Filozoficzne rozważania nad opinia publiczna i poprawnościa polityczna, [in:] Prawa człowieka i ludzkie bezpieczeństwo. Osiagnięcia i wyzwania. W 70. Rocznicę Ogłoszenia Powszechnej Deklaracji Praw Człowieka, Bieńkowska D., Kozłowski R. (ed.), Warszawa 2019.

Bordman E., Freedom of speech and expression in sports, [in:] Arts, communications, entertainment and sports law, New York State 2007.

Chlebowicz P., Tendecje rozwojowe przestępczości zorganizowanej w środowiskach pseudokibiców piłkarskich, [in:] Sport a przestępczość zorganizowana, Leciak M. (ed.), Warszawa 2018.

Coenen P.T.M., Pearson G., Tsoukala A., Legal Responses to Football 'Hooliganism' in Europe - Introduction, [in:] Legal Responses to Football "Hooliganism” in Europe, 2016.

Florczak-Wątor M., Art. 54 Konstytucji RP, [in:] Konstytucja Rzeczypospolitej Polskiej. Komentarz, Tuleja P. (ed.), Warszawa 2019.

Gronowska B., Wolności, prawa i obowiązi człowieka i obywatela, [in:] Prawo Konstytucyjne, Witkowski Z. (ed.), Toruń 2009.

Jadczak S., Wisła w ogniu, Kraków 2019.

Kulk S., Zuiderveen-Borgesius F., Privacy, freedom of expression, and the right to be forgotten in Europe, [in:] The Cambridge Handbook of Consumer Privacy, Polonetsky J., Tene O., Selinger E. (ed.), Cambridge 2018.

Krześniak E., Kluby i organizacje sportowe w prawie polskim na tle rozwiazań zagranicznych, Warszawa 2016.

Łatak T., Polscy kibice-chuligani, Katowice 2011.

McBride M., The Offensive Behaviour at Football and Threatening Communications (Scotland) Act 2012 - Assessing the Case for Repeal, [in:] Edinburgh Law Review 21, nr 2 (May 2017).

Mojski W., Konstytucyjna ochrona wolności wypowiedzi w Polsce, Lublin 2014.

Radke H., Odpowiedzialność dyscyplinarna w sporcie, [in:] Prawo sportowe, Leciak M. (ed.), Warszawa 2018.

Sadomski J., Art. 54 Konstytucji RP, [in:] Konstytucja RP. Tom I. Komentarz do art. 1-86, Safjan M., Bosek L. (ed.), Warszawa 2016. 
Shvets A., Legal Responses to 'Football Hooliganism' in Ukraine, [in:] Legal Responses to Football "Hooliganism” in Europe, Tsoukala A., Pearson G., Coenen P.T.M. (ed.), Oxford 2016.

Wolski D., Regulacje przyjmowane przez międzynarodowe organizacje sportowe a prawo krajowe, [in:] Problemy Wspótczesnego Prawa Międzynarodowego, Europejskiego i Porównawczego, Vol. XIV, Kraków 2016. 